\title{
2-Bromopropane Induced Germ Cell Apoptosis during Spermatogenesis in Male Rat
}

\author{
Guang-Xun $\mathrm{LI}^{1)}$, Kyung-Sun $\mathrm{KANG}^{1)}$ and Yong-Soon $\mathrm{LEE}^{1) *}$ \\ ${ }^{1)}$ Department of Veterinary Public Health, College of Veterinary Medicine, School of Agricultural Biotechnology, Seoul National \\ University, 103 Seodun-dong, Kwonsun-gu, Suwon 441-744, Korea
}

(Received 15 November 2000/Accepted 7 December 2000)

ABSTRACT. 2-Bromopropane (2-BP) causes testicular toxicity in humans and rats. However, the germ cell degeneration of testicular toxicity by 2-BP has not been understood. 2-BP at doses of 135,405 , and $1,355 \mathrm{mg} / \mathrm{kg} / \mathrm{day}$ was daily injected subcutaneously into SpragueDawley rats for 28 days. At the dose of $1,355 \mathrm{mg} / \mathrm{kg} / \mathrm{day}, 2-\mathrm{BP}$ significantly decreased the weights of body and testes, eipididymis, seminal vesicle, and prostate, as well as daily sperm production. Atrophy of seminiferous tubules accompanied with degeneration of germ cells such as spermatogonia, spermatocytes, and elongated spermatids was observed in the testes of rats exposed to the $405 \mathrm{mg} /$ $\mathrm{kg} /$ day and 1,355 mg/kg/day of 2-BP. TUNEL-positive germ cells were appeared in the 405 and 1,355 mg/kg/day of 2-BP-treated groups. In addition, ultrastructure alterations of apoptotic germ cells were observed by the electron microscopy study. Dead elongated spermatids were observed at $1,355 \mathrm{mg} / \mathrm{kg} / \mathrm{day}$ after 28 days exposure. These results suggest that 2-BP impair spermatogenesis may result from apoptotic germ cell death.

KEY WORDS: apoptosis, 2-bromopropane, sperm production, spermatogenesis, testicualr toxicity.

J. Vet. Med. Sci. 63(4): 373-382, 2001

It was reported that male workers suffered oligozoospermia after chronic exposure to 2-BP in an electronics company $[12,14,23]$. Subsequent studies using experimental animals have confirmed the toxic effect of 2-BP on the reproductive organs, such as testes. An inhalation exposure to 300 or $1,000 \mathrm{ppm}$ of 2-BP for 9 weeks decreased body weight, reproductive organ weight, sperm motility, and the number of epididymal sperm $[10,11]$. In addition, severe atrophy of seminiferous tubules and absence of germ cells were also observed in the testes of rats exposed to 2-BP [10, $11,33]$.

A recent study also showed that 2-BP caused necrosis of spermatogonia and spermatocytes in the seminiferous tubules, as well as Leydig cell hyperplasia or hypertrophy in the interstitial tissue [33]. Spermatogonia were damaged by exposure as early as 5 days [22].

$\mathrm{Yu}$ et al. [34] reported, in situ end labeling showed increased numbers of apoptotic oocytes and granulosa cells in primordial follicles at days 5 and 17 after inhalation exposure of 3,000 ppm 2-BP. This result suggested that ovarian dysfunction induced by 2-BP was caused by the destruction of primordial follicle and its oocyte due to the induction of apoptosis in female rats.

However, the mechanism of the germ cell degeneration of 2-BP is poorly understood. Therefore, the aim of this study is to determine the cause of dysfunction of spermatogenesis, and clarify the action mechanism of germ cell death. We examined the qualitative and quantitative characteristics involved in spermatogenesis, testicular atrophy and germ cell degeneration, and examined a possible involvement of apoptosis in the spermatogenic cell death in male rats.

\footnotetext{
* Correspondence to: Lee, Y.-S., Department of Veterinary Public Health, College of Veterinary Medicine, Seoul National University, 103 Seodun-dong, Kwonsun-gu, Suwon 441-744, Korea.
}

\section{MATERIALS AND METHODS}

Animals: Eighty-eight male Sprague-Dawley (SD) rats (specific pathogen-free, 9 weeks) were purchased from Samyouk Laboratory Animal Center (Osan, Korea). The animals were acclimatized for 1 week under an environmentally controlled room (temperature: $22 \pm 3{ }^{\circ} \mathrm{C}$, relative humidity: $55 \pm 5 \%$, air circulation frequency: 10-12 times/ hr, artificial light: 150-300 Lux from 7 a.m. to 7 p.m.). The eighty-eight male rats were housed in polycarbonate cages and had free access to a pellet diet (Purina Co., Korea) and tap water.

Chemicals and treatment: 2-BP was obtained from Fluka Chemical Co. (U.S.A). The purity of $2-$ BP was $>99 \%$ by gas chromatography. A total of 60 rats were divided into 4 groups. There were four experimental groups including one sham control group and three 2-BP-treated groups. According to these data, male rats were daily subcutaneously exposed to 2-BP at the doses of 135,405 , and $1,355 \mathrm{mg} / \mathrm{kg} /$ day for 28 days. This range of dose levels encompassed the highest level used in the Omura et al. [22], Ichihara et al. [10, 11], and Yu et al. [34] study to target a dose that caused reproductive tract toxicity. Control rats received corn oil (1 $\mathrm{m} l / \mathrm{kg} /$ day).

Body and organ weights: The male rats were weighed twice weekly after $6,12,18,24$, and 28 days. Five male rats from each group were sacrificed under anesthesia after 7 , 14,21 , and 28 days treatment. There were exsanguinated by aortic puncture. At sacrifice, testes, epididymides, seminal vesicles, and prostate were weighed and their weights relative to brain weight calculated.

Daily sperm production: Daily sperm production in right testes of 2-BP treated rats was examined at 14 and 28 days after exposure. Daily sperm production was measured in male rats at 14 and 28 day after exposure as described by 
Blazak et al. [6]. Briefly, testes were thawed in ice, decapsulated, and homogenized in $50 \mathrm{~m} l$ of ice-cold $0.9 \% \mathrm{NaCl}$ solution containing $0.01 \%$ Triton $\mathrm{X}-100$ using a tissue homogenizer (Fisher Scientific, U.S.A.). The homogenate was allowed to settle for $1 \mathrm{~min}$, and then was gently mixed and a $10-\mathrm{m} l$ aliquot was collected into a glass vial and stored on ice. After thorough mixing of each sample, the number of sperm heads was counted by hemocytometer. The number of sperm produced per gram of testicular tissue was calculated according to the following formula: average count of sperm heads from four chambers $\times$ square factor (which is 5) $\times$ hemocytometer factor (which is $10^{4}$ ) $\times$ dilution factor (which is 50) divided by testis weight ( $\mathrm{g}$ ) and the time (days) during spermatogenesis that these cells are resistant to homogenization which is 6.1 days for rats according to Blazak et al. [6]. The data are expressed as the means \pm SD.

Histopathological examination: Five rats of each group were sacrificed for examination of histopathological finding at $7,14,21$, and 28 days. Left testes were fixed in Bouin's solution, dehydrated, embedded in paraffin, transversely cut into 3- $\mu \mathrm{m}$ sections, and stained with hematoxylin and eosin (H\&E) or Periodic Acid-Schiff's reagent (PAS). Histopathological evaluation of the testis was performed according to the method described by Creasy [8] and Matsui et al. [17].

Evaluation of spermatogenesis in the seminiferous tubules: Left testes of 5 rats of each group at 14 and 28 day after 2-BP exposure were fixed in Bouin's solution, embedded in paraffin, sectioned and then stained with Periodic Acid Schiff's reagent (PAS). The numbers of Sertoli cells, spermatogonia (Type A and B), preleptotene spermatocytes, leptotene spermatocytes, zygotene spermatocytes, pachytene spermatocytes, round spermatids, and elongated spermatids were counted at stages II-III, V, VII, and XII in a total of 10 round or ovoid seminiferous tubules [17]. These stages were chosen as representative to include morphologically identifiable stages. Spermatogenic staging evaluation of the testis was performed according to the method described by Takahashi and Matsui [30] and Creasy [8].

Determination of apoptotic germ cells: In situ detection of individual germ cells with DNA strand breaks in paraffinembedded left testicular sections $(5-\mu \mathrm{m})$ was achieved by the TUNEL method using an AopoTag-Peroxidase Kit (S7100, Intergen Co.). Briefly, digoxidase-UTP-labeled DNA was detected with anti-digoxigenin-peroxidase antibody followed by peroxidase detection with $0.05 \%$ diaminobenzidine (DAB) and $0.02 \%$ hydrogen peroxide. Sections were counter stained with $0.5 \%$ methyl green $[1,3$, 31].

The apoptotic germ cells were determined by the dark brown staining (DAB stained) patterns of nucleus. The number of apoptotic germ cells was counted in 200 randomly selected seminiferous tubules of five animals testis cross sections from each of the time points $(0,1,2,3$, and 4 weeks). The incidences of apoptotic cells were then categorized into either of four groups defined as $1-3,4-6,7-9$, or $\geq 10$ positive cells per tubule, respectively [24]. A total of seminiferous tubule cross sections was analyzed for each animal and data were expressed as percentages of total.

Electron microscopic examination: The testes of 2 rats of high dose group were sacrificed for examination of germ cell death type in electron microscopy at 7, 14, 21, and 28 day after exposure. The testes were fixed by perfusion via the abdominal aorta as follows. The animals were anesthesized with ethyl ether, and a polyethylene tube was inserted into the aorta through the left ventricle of the heart [9]. After an initial flush with cacodylate-buffered saline for about $1 \mathrm{~min}$, a mixture of $0.1 \mathrm{M}$ cacodylate-buffered $2 \%$ paraformaldehyde and $2.5 \%$ glutaraldehyde ( $\mathrm{PH} 7.4)$ was perfused at room temperature for $30 \mathrm{~min}$. Perfusion was carried out at a pressure of $700-800 \mathrm{mmH}_{2} \mathrm{O}$. After fixation, the testes were removed and weighed, and then small blocks of them were fixed with $0.1 \mathrm{M}$ cacodylate buffered $1 \%$ osmium tetroxide and embedded in epoxy resin (Fluka, Chemical Co., U.S.A.) [4, 26, 29]. Semithin sections were stained with toluidine blue and observed with a light microscope. Ultrathin section stained with uranyl acetate and lead citrate were prepared from a representative area and observed with a transmission electron microscope (JEOL, JEM-100CX).

Statistical analysis: All of the quantitative data, calculated as a percentage of total were expressed as the mean \pm SD. Significantly differences between groups $(\mathrm{p}<0.05)$ were determined using the Duncan's multiple range test after single factor analysis of variance.

\section{RESULTS}

Body weight and organ weight: Body weight gain was suppressed in a dose-dependent manner by 2-BP exposure (Fig. 1). At the dose of 405 or $1,355 \mathrm{mg} / \mathrm{kg} /$ day after 28 days treatment, 2-BP significantly decreased the weights of body, compared to the control group. But low dose of 135 $\mathrm{mg} / \mathrm{kg} /$ day did not significantly decrease the body weights compared to the control group.

At the dose of $1,355 \mathrm{mg} / \mathrm{kg} /$ day of $2-\mathrm{BP}$ after 14 days treatment, absolute organ weights of the testes were significantly decreased, but other organ weights were not decreased (Table 1). The absolute and relative organ weights of the testes, epididymides, seminal vesicles, and prostate were also significantly decreased at the dose of $1,355 \mathrm{mg} / \mathrm{kg} /$ day of 2 -BP after 28 -day treatment. In addition, the relative organ weight of seminal vesicles was significantly decreased at the dose of $405 \mathrm{mg} / \mathrm{kg} /$ day (Table 2). The body and organ weights data at 7 and 21 days are not shown.

Daily sperm production: At all doses, the treatment with 2-BP for 14 days, did not significantly decrease daily sperm production (Table 3). However, at the dose of 405 or 1,355 $\mathrm{mg} / \mathrm{kg} /$ day after 28 days treatment with 2-BP, daily sperm production in testes was significantly decreased, compared to the control (Table 3).

Histopathological examination: The testicular lesions 


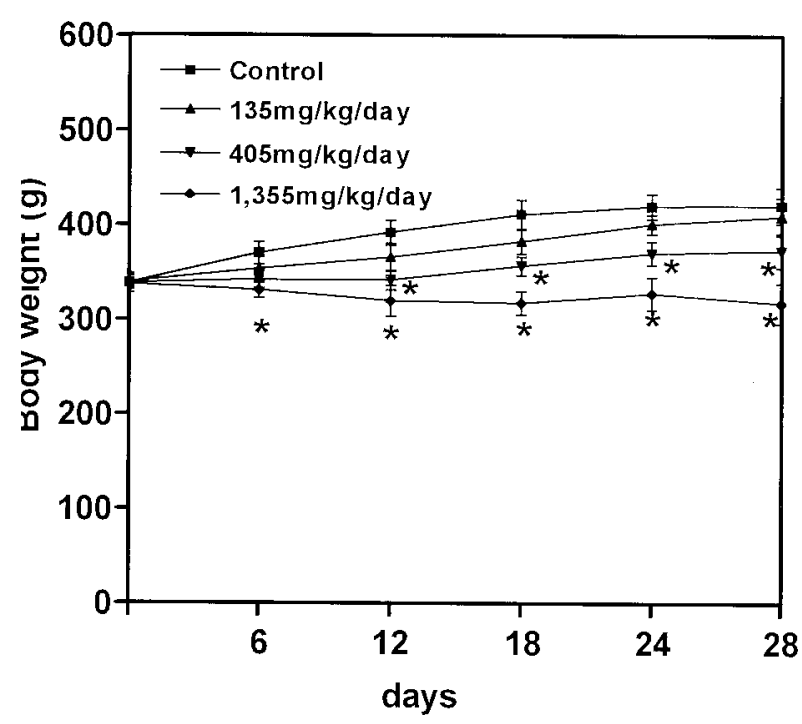

Fig. 1. Body weight changes of male rats by daily exposure of 2-BP. Values represent the mean \pm SD. *, Significantly different from the control $(\mathrm{P}<0.05)$. following 2-BP exposure are summarized in Tables 4 and 5. The dose of $1,355 \mathrm{mg} / \mathrm{kg} /$ day caused slight degeneration of germ cells in the seminiferous epithelium in rats treated with 2-BP for 14 days. In addition, degeneration of spermatocytes and spermatids, vacuolization of Sertoli cells, multinuclear giant cell, and Sertoli cell only tubules were observed rich in rats treated with $1,355 \mathrm{mg} / \mathrm{kg} / \mathrm{day}$ of $2-\mathrm{BP}$ for 28 days (Fig. 2). In addition, the dose of $405 \mathrm{mg} / \mathrm{kg} /$ day of 2-BP also caused vacuolization of Sertoli cells, multinuclear giant cells, and degeneration of germ cells. However, the dose of $135 \mathrm{mg} / \mathrm{kg} /$ day group was not affected (photograph not shown). Numerous exfoliated germ cells were observed in the lumen of epididymal ducts at the dose of $405,1,355 \mathrm{mg} / \mathrm{kg} /$ day of 2-BP treatment for 28 days (photograph not shown).

Evaluation of spermatogenic cell in the seminiferous tubules: At the doses of 405 and 1,355 mg/kg/day, the treatment with 2-BP for 14 and 28 days was significantly decreased spermatogenesis at all the stages. The number of Sertoli cells, spermatogonia, preleptotene spermatocytes, zygotene spermatocytes, pachytene spermatocytes, round spermatids, and elongated spermatids in seminiferous

Table 1. Organ weights in male rats treated with 2-bromopropane for 14 days

\begin{tabular}{lcccc}
\hline & \multicolumn{4}{c}{ 2-BP $(\mathrm{mg} / \mathrm{kg} / \mathrm{day})$} \\
\cline { 2 - 5 } & Control & 135 & 405 & 1,355 \\
\hline No. of males & 5 & 5 & 5 & 5 \\
Absolute organ weight (g) & & & & \\
Testes & $1.45 \pm 0.15^{\mathrm{a})}$ & $1.43 \pm 0.25$ & $1.39 \pm 0.34$ & $1.17 \pm 0.13^{*}$ \\
Epididymis & $0.29 \pm 0.17$ & $0.30 \pm 0.16$ & $0.27 \pm 0.18$ & $0.26 \pm 0.20$ \\
Seminal vesicle & $0.86 \pm 0.14$ & $0.85 \pm 0.26$ & $0.81 \pm 0.23$ & $0.78 \pm 0.27$ \\
Prostate & $0.60 \pm 0.27$ & $0.61 \pm 0.21$ & $0.57 \pm 0.16$ & $0.53 \pm 0.28$ \\
Relative organ weight (\%) & & & & \\
Testes & $75.77 \pm 2.26$ & $76.23 \pm 3.23$ & $74.67 \pm 4.34$ & $69.24 \pm 2.87$ \\
Epididymis & $17.26 \pm 1.45$ & $17.02 \pm 1.84$ & $16.86 \pm 1.59$ & $16.74 \pm 1.56$ \\
Seminal vesicle & $44.57 \pm 6.53$ & $43.46 \pm 5.76$ & $41.23 \pm 4.67$ & $38.78 \pm 4.57$ \\
Prostate & $20.34 \pm 15.63$ & $21.32 \pm 9.68$ & $19.89 \pm 4.35$ & $18.79 \pm 6.58$ \\
\hline
\end{tabular}

a) Values represent the means \pm SD.

* Significantly different from the control $(\mathrm{p}<0.05)$.

Table 2. Organ weights in male rats treated with 2-bromopropane for 28 days

\begin{tabular}{lcccc}
\hline & \multicolumn{4}{c}{ 2-BP (mg/kg/day) } \\
\cline { 2 - 5 } & Control & 135 & 405 & 1,355 \\
\hline No. of males & 5 & 5 & 5 & 5 \\
Absolute organ weight (g) & & & & \\
Testes & $1.58 \pm 0.91^{\mathrm{a})}$ & $1.52 \pm 0.15$ & $1.46 \pm 0.89$ & $1.15 \pm 0.23^{*}$ \\
Epididymis & $0.39 \pm 0.19$ & $0.35 \pm 0.19$ & $0.33 \pm 0.15$ & $0.28 \pm 0.16^{*}$ \\
Seminal vesicle & $0.96 \pm 0.15$ & $0.81 \pm 0.22$ & $0.76 \pm 0.19$ & $0.52 \pm 0.07^{*}$ \\
Prostate & $0.66 \pm 0.26$ & $0.69 \pm 0.11$ & $0.65 \pm 0.26$ & $0.41 \pm 0.08^{*}$ \\
Relative organ weight (\%) & & & & \\
Testes & $79.86 \pm 4.26$ & $79.80 \pm 3.50$ & $78.81 \pm 5.12$ & $63.08 \pm 6.58^{*}$ \\
Epididymis & $19.30 \pm 2.29$ & $17.88 \pm 1.48$ & $17.43 \pm 1.82$ & $16.83 \pm 1.04^{*}$ \\
Seminal vesicle & $48.44 \pm 8.14$ & $41.14 \pm 6.88$ & $35.45 \pm 6.88^{*}$ & $27.95 \pm 3.75^{*}$ \\
Prostate & $33.30 \pm 13.75$ & $35.25 \pm 7.69$ & $31.25 \pm 2.31$ & $21.98 \pm 4.99^{*}$ \\
\hline
\end{tabular}

a) Values represent the means \pm SD.

* Significantly different from the control $(\mathrm{p}<0.05)$. 
Table 3. Numbers of sperm count and the sperm motile in the rats treated with 2-bromopropane for 14 and 28 day

\begin{tabular}{lcccc}
\hline & \multicolumn{4}{c}{$2-\mathrm{BP}(\mathrm{mg} / \mathrm{kg} /$ day $)$} \\
\cline { 2 - 5 } & Control & 135 & 405 & 1,355 \\
\hline $\begin{array}{l}\text { No. of males } \\
\begin{array}{l}14 \text { days treatment } \\
\text { Daily sperm production } \\
\left(\times 10^{8} / \mathrm{g} \text { testis/day) }\right.\end{array}\end{array}$ & 5 & 5 & 5 & 5 \\
28 days treatment & $20.51 \pm 2.71^{\mathrm{a})}$ & $20.63 \pm 3.05$ & $20.12 \pm 2.25$ & $18.65 \pm 2.78$ \\
$\begin{array}{c}\text { Daily sperm production } \\
\left(\times 10^{8} / \mathrm{g} \text { testis/day }\right)\end{array}$ & $20.11 \pm 2.42$ & $19.38 \pm 1.95$ & $16.14 \pm 1.28^{*}$ & $11.03 \pm 3.41^{*}$ \\
\hline
\end{tabular}

a) Values represent the means \pm SD.

* Significantly different from the control $(\mathrm{p}<0.05)$.

Table 4. Histopathological findings for male adult rats treated with 2-bromopropane for 14 days

\begin{tabular}{lcccc}
\hline & \multicolumn{4}{c}{$2-\mathrm{BP}(\mathrm{mg} / \mathrm{kg} / \mathrm{day})$} \\
\cline { 2 - 5 } & Control & 135 & 405 & 1,355 \\
\hline No. examined & 5 & 5 & 5 & 5 \\
Findings & & & & \\
Seminiferous tubule atrophy & 0 & 0 & 0 & 1 \\
Degeneration of spermatocytes & 0 & 0 & 0 & 3 \\
Degeneration of spermatids & 0 & 0 & 0 & 3 \\
Vacuolization of Sertoli cells & 0 & 0 & 0 & 1 \\
Multi nucleated giant cells & 0 & 0 & 0 & 0 \\
Sertoli cell only seminiferous tubules & 0 & 0 & 0 & 0
\end{tabular}

Table 5. Histopathological findings for male adult rats treated with 2-bromopropane for 28 days

\begin{tabular}{lcccc}
\hline & \multicolumn{3}{c}{ 2-BP $(\mathrm{mg} / \mathrm{kg} / \mathrm{day})$} \\
\cline { 2 - 5 } & Control & 135 & 405 & 1,355 \\
\hline No. examined & 5 & 5 & 5 & 5 \\
Findings & & & 3 & 5 \\
Seminiferous tubule atrophy & 0 & 0 & 3 & 5 \\
Degeneration of spermatocytes & 0 & 0 & 3 & 5 \\
Degeneration of spermatids & 0 & 0 & 4 & 5 \\
Vacuolization of Sertoli cells & 0 & 0 & 2 & 5 \\
Multi nucleated giant cells & 0 & 0 & 3 & 4 \\
Sertoli cell only seminiferous tubules & 0 & 0 & & \\
\hline
\end{tabular}

tubules were significantly low, compared to the control (Tables 6 and 7). However, the lowest dose of $135 \mathrm{mg} / \mathrm{kg} /$ day of 2-BP for 14 and 28 days did not affect the spermatogenic germ cells in the testes (Tables 6 and 7).

Evaluation of apoptotic germ cells: TUNEL-positive apoptotic germ cells (dark brown) was investigated by the in situ TUNEL staining (Fig. 3). At the dose of 405 or 1,355 $\mathrm{mg} / \mathrm{kg} /$ day, 2-BP evidently induced TUNEL-positive cells in seminiferous epithelium. At the dose of $405 \mathrm{mg} / \mathrm{kg} / \mathrm{day}$, the TUNEL-positive cells were time-dependently increased (Fig. 4A). The apoptotic germ cells were the most frequently detected at the dose of $1,355 \mathrm{mg} / \mathrm{kg} /$ day on week 2 (Fig. 4B). However, at the dose of $1,355 \mathrm{mg} / \mathrm{kg} /$ day on week 3 or 4 , the TUNEL-positive cells were slightly decreased, compared to week 2 (Fig. 4B).

Electron microscopic observations: Electron microscopic examination was performed the marked nuclear chromatin condensation, cytoplasmic condensation, and preservation of the integrity of organelles in the treatment of 2-BP with the highest dose of $1,355 \mathrm{mg} / \mathrm{kg} /$ day for 14 days (Fig. 5). The exposure to 2-BP for 14, 21, and 28 days caused degeneration of many round spermatids and elongated spermatids. The dead elongated spermatids were observed in the seminiferous epithelium on day 21 or 28 at the dose of $1,355 \mathrm{mg} /$ kg/day (Fig. 6). However, germ cell alternation was not observed on day 7 . 

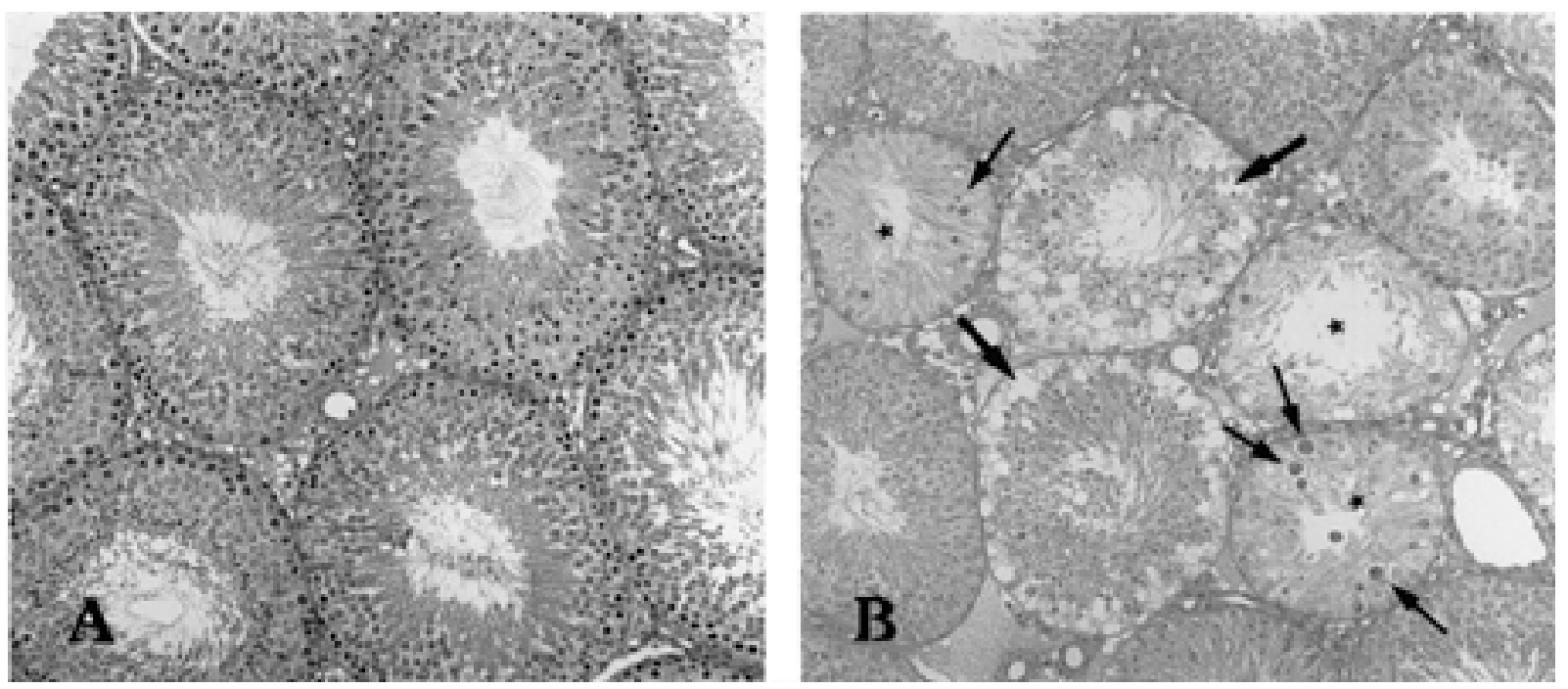

Fig. 2. Photomicrograph of the seminiferous tubules from a control (A) and a 1,355 mg/kg/day 2-BP treated at 28 day (B). Note the multi giant cell formation (small arrows) and Sertoli cell vacuolization (large arrows), absent all types germ cells, degeneration of germ cell in lumen (arrowhead), defined Sertoli cell only tubules (stars).

Table 6. Cell types and numbers in seminiferous tubules of male rats treated with 2-bromopropane for 14 days

\begin{tabular}{|c|c|c|c|c|}
\hline Dose (mg/kg/day) & Control & 135 & 405 & 1,355 \\
\hline No. of males & 5 & 5 & 5 & 5 \\
\hline \multicolumn{5}{|l|}{ Stages II-III } \\
\hline Sertoli cells & $16.64 \pm 3.64^{\text {a) }}$ & $15.36 \pm 2.36$ & $14.34 \pm 1.87$ & $11.59 \pm 2.73^{*}$ \\
\hline Spermatogonia & $21.25 \pm 4.79$ & $21.10 \pm 5.46$ & $19.26 \pm 5.73$ & $14.72 \pm 5.32 *$ \\
\hline Pachytene Spermatocytes & $55.48 \pm 5.45$ & $52.54 \pm 5.36$ & $48.50 \pm 4.24 *$ & $36.60 \pm 4.59 *$ \\
\hline Round Spermatids & $148.63 \pm 13.47$ & $149.47 \pm 14.50$ & $146.00 \pm 13.27$ & $128.20 \pm 15.12$ \\
\hline Elongate Spermatids & $156.30 \pm 15.25$ & $154.40 \pm 14.23$ & $148.73 \pm 18.37$ & $139.00 \pm 20.32$ \\
\hline \multicolumn{5}{|l|}{ Stages V } \\
\hline Sertoli cells & $15.40 \pm 1.47$ & $16.28 \pm 1.84$ & $15.24 \pm 2.57$ & $10.27 \pm 2.37 *$ \\
\hline Spermatogonia (Type A and B) & $27.40 \pm 2.67$ & $26.32 \pm 2.60$ & $17.26 \pm 3.47^{*}$ & $13.47 \pm 4.29^{*}$ \\
\hline Pachytene Spermatocytes & $60.75 \pm 5.35$ & $57.34 \pm 3.48$ & $53.40 \pm 5.85$ & $21.60 \pm 6.26^{*}$ \\
\hline Round Spermatids & $154.20 \pm 19.83$ & $146.46 \pm 15.64$ & $143.00 \pm 14.83$ & $126.00 \pm 17.58^{*}$ \\
\hline Elongate Spermatids & $150.75 \pm 6.86$ & $150.65 \pm 7.53$ & $147.43 \pm 13.40$ & $121.00 \pm 14.39 *$ \\
\hline \multicolumn{5}{|l|}{ Stages VII } \\
\hline Sertoli cells & $16.64 \pm 2.74$ & $15.57 \pm 2.71$ & $14.53 \pm 1.85$ & $9.34 \pm 2.06^{*}$ \\
\hline Spermatogonia & $3.50 \pm 1.05$ & $3.46 \pm 1.32$ & $1.43 \pm 1.24^{*}$ & $1.00 \pm 1.67 *$ \\
\hline Preleptotene Spermatocytes & $37.03 \pm 2.48$ & $33.85 \pm 3.20$ & $30.40 \pm 4.82$ & $25.74 \pm 6.45^{*}$ \\
\hline Pachytene Spermatocytes & $45.94 \pm 4.74$ & $46.54 \pm 6.45$ & $41.64 \pm 9.35$ & $32.75 \pm 8.94 *$ \\
\hline Round Spermatids & $180.40 \pm 12.43$ & $175.63 \pm 13.45$ & $157.43 \pm 17.48$ & $137.89+20.74 *$ \\
\hline Elongate Spermatids & $142.30 \pm 12.84$ & $138.87 \pm 15.46$ & $123.75 \pm 16.76$ & $117.95 \pm 21.45^{*}$ \\
\hline \multicolumn{5}{|l|}{ Stages XII } \\
\hline Sertoli cells & $18.83 \pm 1.85$ & $18.48 \pm 1.90$ & $17.78 \pm 0.75$ & $13.64 \pm 1.98^{*}$ \\
\hline Spermatogonia & $5.36 \pm 0.84$ & $4.65 \pm 1.24$ & $2.58 \pm 0.75^{*}$ & $1.55 \pm 1.24 *$ \\
\hline Zygotene Spermatocytes & $50.45 \pm 4.85$ & $48.56 \pm 2.54$ & $42.70 \pm 5.64$ & $31.73+5.60^{*}$ \\
\hline Pachytene Spermatocytes & $56.58 \pm 5.64$ & $54.85 \pm 7.73$ & $44.65 \pm 6.58^{*}$ & $37.67+7.47 *$ \\
\hline Elongate Spermatids & $167.64 \pm 17.50$ & $164.45 \pm 18.64$ & $157.67 \pm 19.54$ & $112.87 \pm 20.43^{*}$ \\
\hline
\end{tabular}

a) Values represent the means \pm SD.

* Significantly different from the control $(\mathrm{p}<0.05)$. 
Table 7. Cell types and numbers in seminiferous tubules of male rats treated with 2-bromopropane for 28 days

\begin{tabular}{|c|c|c|c|c|}
\hline $\begin{array}{l}\text { Dose }(\mathrm{mg} / \mathrm{kg} / \text { day }) \\
\text { No. of males }\end{array}$ & $\begin{array}{c}\text { Control } \\
5\end{array}$ & $\begin{array}{c}135 \\
5\end{array}$ & $\begin{array}{c}405 \\
5\end{array}$ & $\begin{array}{c}1,355 \\
5\end{array}$ \\
\hline \multicolumn{5}{|l|}{ Stages II-III } \\
\hline Sertoli cells & $18.74 \pm 2.13^{\mathrm{a})}$ & $16.10 \pm 1.28$ & $13.38 \pm 1.64^{*}$ & $9.21 \pm 1.08 *$ \\
\hline Spermatogonia & $23.26 \pm 5.25$ & $21.33 \pm 5.27$ & $10.45 \pm 3.92 *$ & $2.56 \pm 4.09^{*}$ \\
\hline Pachytene Spermatocytes & $56.60 \pm 4.45$ & $51.34 \pm 5.55$ & $33.60 \pm 2.07 *$ & $10.60 \pm 2.19 *$ \\
\hline Round Spermatids & $151.40 \pm 15.65$ & $149.29 \pm 13.50$ & $106.00 \pm 10.07 *$ & $85.00 \pm 12.83^{*}$ \\
\hline Elongate Spermatids & $157.20 \pm 17.25$ & $150.60 \pm 12.33$ & $100.65 \pm 22.87 *$ & $93.00 \pm 25.12 *$ \\
\hline \multicolumn{5}{|l|}{ Stages V } \\
\hline Sertoli cells & $16.83 \pm 1.64$ & $14.64 \pm 1.05$ & $12.47 \pm 0.84^{*}$ & $8.84 \pm 2.67^{*}$ \\
\hline Spermatogonia & $21.80 \pm 4.09$ & $22.20 \pm 3.30$ & $11.40 \pm 2.07 *$ & $1.26 \pm 2.67 *$ \\
\hline Pachytene Spermatocytes & $62.40 \pm 8.08$ & $55.14 \pm 3.54$ & $43.60 \pm 3.94 *$ & $21.60 \pm 6.26^{*}$ \\
\hline Round Spermatids & $154.20 \pm 19.83$ & $146.46 \pm 15.64$ & $143.00 \pm 14.83$ & $106.00 \pm 16.99 *$ \\
\hline Elongate Spermatids & $155.80 \pm 4.97$ & $151.65 \pm 7.89$ & $137.75 \pm 20.26$ & $96.00 \pm 24.47 *$ \\
\hline \multicolumn{5}{|l|}{ Stages VII } \\
\hline Sertoli cells & $17.72 \pm 2.75$ & $14.97 \pm 1.63$ & $11.06 \pm 0.64^{*}$ & $9.75 \pm 0.94 *$ \\
\hline Spermatogonia & $4.40 \pm 1.14$ & $3.35 \pm 1.14$ & $1.60 \pm 1.24 *$ & $1.06 \pm 2.14 *$ \\
\hline Preleptotene Spermatocytes & $36.40 \pm 3.58$ & $34.78 \pm 2.70$ & $23.60 \pm 3.96^{*}$ & $15.57 \pm 5.12 *$ \\
\hline Pachytene Spermatocytes & $47.80 \pm 3.83$ & $45.16 \pm 2.68$ & $38.57 \pm 8.01^{*}$ & $20.79 \pm 7.19^{*}$ \\
\hline Round Spermatids & $173.20 \pm 7.60$ & $164.56 \pm 14.21$ & $116.00 \pm 14.81^{*}$ & $108.00 \pm 22.36^{*}$ \\
\hline Elongate Spermatids & $139.60 \pm 9.41$ & $134.76 \pm 14.56$ & $113.85 \pm 18.43$ & $91.78 \pm 17.25^{*}$ \\
\hline \multicolumn{5}{|l|}{ Stages XII } \\
\hline Sertoli cells & $18.84 \pm 2.73$ & $17.05 \pm 1.65$ & $12.84 \pm 0.67$ & $12.05 \pm 1.93^{*}$ \\
\hline Spermatogonia & $4.6 \pm 1.00$ & $3.6 \pm 1.14$ & $1.48 \pm 0.84^{*}$ & $1.15 \pm 0.74 *$ \\
\hline Zygotene Spermatocytes & $48.78 \pm 2.43$ & $50.13 \pm 1.54$ & $29.60 \pm 4.96^{*}$ & $11.63 \pm 6.30 *$ \\
\hline Pachytene Spermatocytes & $57.89 \pm 4.45$ & $56.84 \pm 7.82$ & $30.51 \pm 3.69^{*}$ & $7.92 \pm 6.37 *$ \\
\hline Elongate Spermatids & $148.40 \pm 14.52$ & $150.21 \pm 16.83$ & $137.23 \pm 17.64$ & $82.47 \pm 21.32 *$ \\
\hline
\end{tabular}

a) Values represent the means \pm SD.

* Significantly different from the control $(\mathrm{p}<0.05)$.
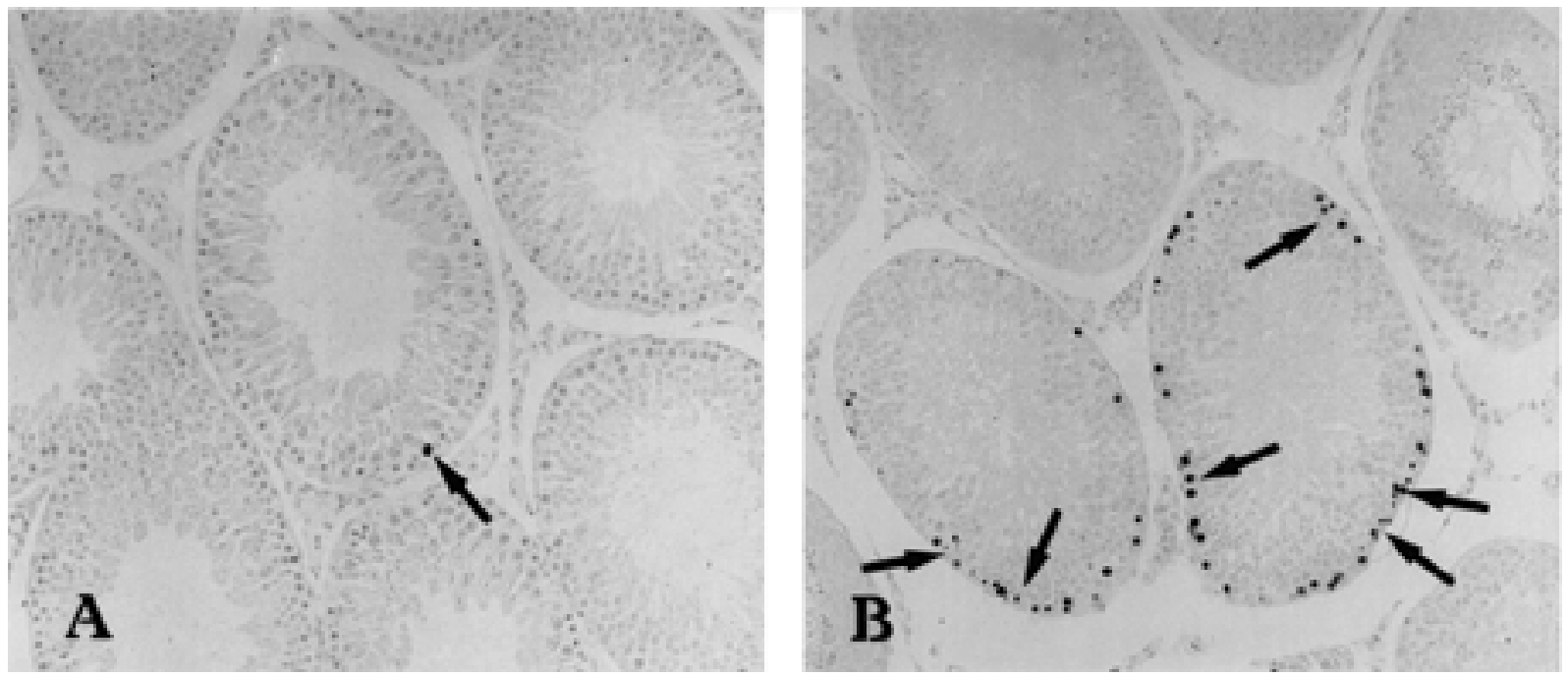

Fig. 3. Photomicrograph of the TUNEL-positive apoptotic germ cells (arrows) from a control (A) and 1,355 mg/kg/day 2-BP treated at 14 day (B). A characteristic feature of apoptosis was detected in germ cells by TUNEL staining of testis cross sections. Number of TUNEL positive events markedly increased over that control at 14 days (B).

\section{DISCUSSION}

Kim et al. [13] reported that the workers in a Korean electronic company were exposed to 2-BP with more than 4,000 ppm as a short-term exposure. Ambient concentrations of 2-
BP were from $9.2 \mathrm{ppm}$ to $19.6 \mathrm{ppm}$ in the workplace during regular operation after improvement of ventilation. Therefore, Ichihara et al. [11] reported that the real exposure concentrations were not evaluated in the field survey, but 300 ppm to 3,000 ppm exposure could have been possible in the 

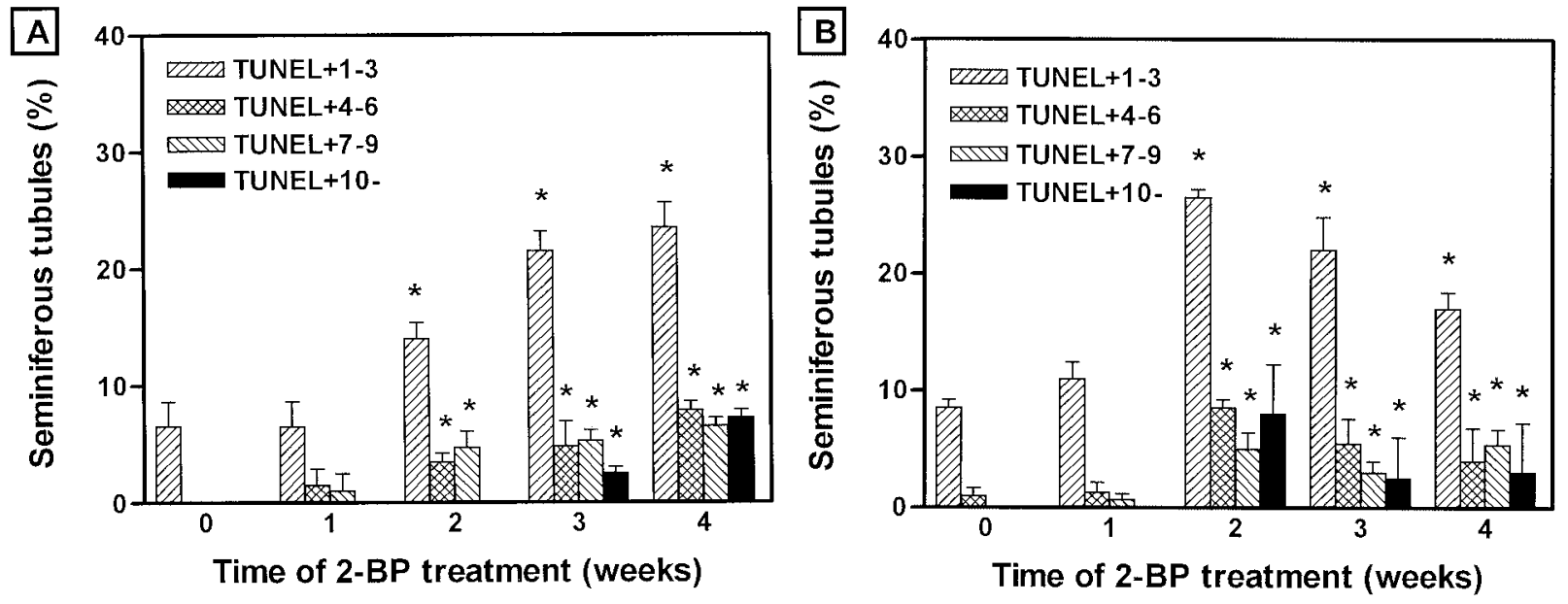

Fig. 4. Quantitative of apoptosis by TUNEL staining in testis cross sections from control and 2-BP treated of 405 (A) and 1,355 (B) mg/kg/ day rats. The apoptosis was determined by TUNEL-positive cells for each seminiferous tubule, and TUNEL-positive appearance tubules were categorized 1-3, 4-6, 7-9, or $\leq 10$ positive cells per tubule. A total of 200 randomly selected tubule cross sections were analyzed at each time point with data expressed as a percentage per total. Each bar represent the means \pm SD. *, Significantly different from the control $(\mathrm{p}<0.05)$.

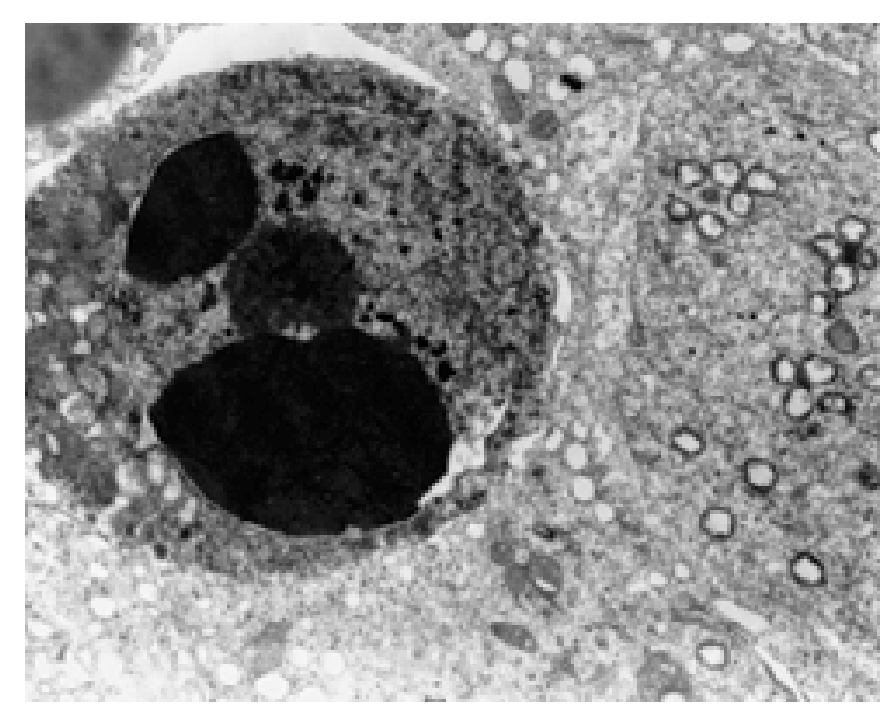

Fig. 5. Electron micrographs of apoptotic pachytene spermatocyte from exposed to dose of $1,355 \mathrm{mg} / \mathrm{kg} / \mathrm{day} 2$-BP at 14 days. The apoptotic pachytene spermatocytes showed characteristic marked nuclear chromatin fragment, cytoplasmic condensation and preservation of the integrity of organelles.

Korean workplace judged from the above data.

The range of doses $135-1,355 \mathrm{mg} / \mathrm{kg} /$ day in this study used in the Omura et al. [22], Ichihara et al. [10,11], and Yu et al. [34] study to target a dose that caused reproductive tract toxicity. Dosage of 2-BP at 135, 405, and 1,355 mg/ $\mathrm{kg} /$ day exposure level is calculated to be approximately 100 , 300 , and 1,000 ppm of inhalation exposure [22].

The electronic factory workers in Korea did not use personal protective devices such as gloves and masks to treat cleaning bath, resulting in skin contact with the solvent. In addition, they often dipped a glass of the cleaning solution from the bath by hand [23]. Therefore, absorption through the cutaneous respiration may also be responsible for the uptake of 2-BP into the human body, but this was not investigated in the present study. Therefore, a subcutaneous exposure would be applied in this study.

Daily sperm production parameter in the testis can be used as a valid assay of spermatogonia survival for cytotoxic agents [18]. Sperm production is still reduced at 56 days after treatment with chemicals that kill spermatogonia 


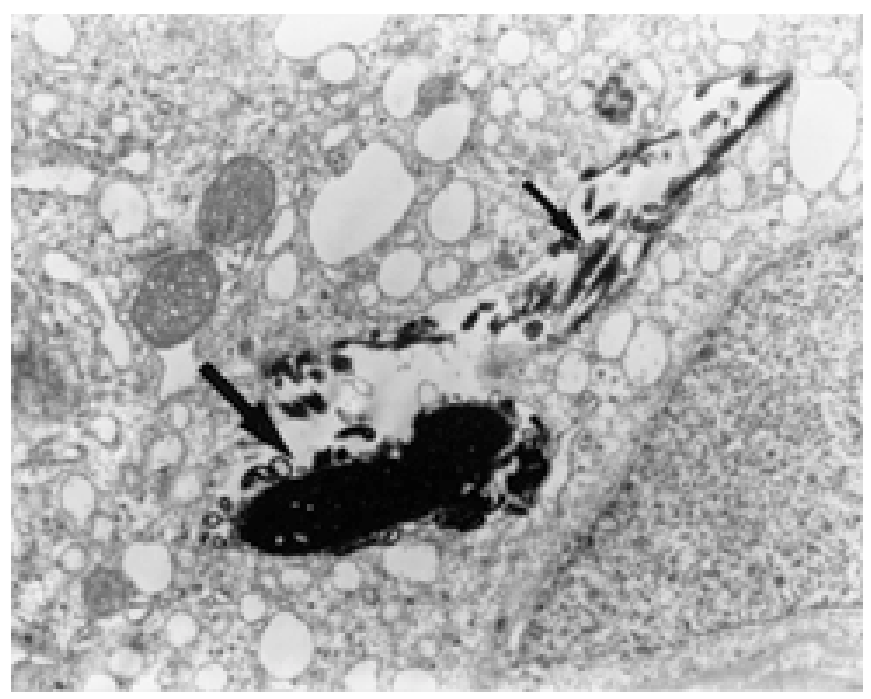

Fig. 6. Note the dead elongated spermatid was observed in seminiferous epithelium from exposed to $1,355 \mathrm{mg} / \mathrm{kg} / \mathrm{day}$ of $2-\mathrm{BP}$ at 28 days. The large arrow is spermatid head; the small arrow is flagellum of spermatid; N, Sertoli Cell Nucleus.

[16]. At the dose of 405 and $1,355 \mathrm{mg} / \mathrm{kg} /$ day, daily sperm production in the testis for 28 days exposure was significantly decreased compared to the control. In addition, testis and epididymis weight were significantly decreased at the dose of $1,355 \mathrm{mg} / \mathrm{kg} /$ day on day 28 . These results suggest that the 2-BP treatment may be induced the testicular spermatogenic functional changes.

In this study, the numbers of spermatogonia, preleptotene spermatocytes, pachytene spermatocytes, zygotene spermatocyte, round spermatids, and elongated spermatids were significantly decreased in the seminiferous tubules at the stages II-III, V, VII and XII at the dose of 405 or $1,355 \mathrm{mg} /$ $\mathrm{kg} / \mathrm{day}$ on day 28 . The toxicity of 2-BP primarily targets to spermatogonia [21, 22]. Spermatogonia represent the first stage of differentiation in spermatogenesis and are located just above the basement membrane of the seminiferous tubules. In this study, the differentiating spermatogonia are the primary target for 2-BP. Duration of one cycle of the seminiferous epithelium is about 12.9 days $(310.9 \mathrm{~h})$ in rats [7]. In this study, the exposure of 28 days corresponds approximately 2 cycles of spermatogenesis stage. Therefore, the developing germ cell types in the seminiferous epithelium were affected for 2-cycle spermatogenic stage. In Fig. 2, the germ cells such as spermatogonia and spermatocytes in the basal epithelium were first degenerated, following the vacuolization of the Sertoli cells. In addition, the germ cells damaged by 2 -BP were changed gradually into adluminal epithelium shapes. These findings suggest that 2$\mathrm{BP}$ exposure cause the loss of the spermatogonia, spermatocytes, and elongated spermatids in a time-dependent manner.

The exposure to 2-BP caused atrophy of seminiferous tubules, degeneration of germ cell, vacuolization of Sertoli cells, multinuclear giant cell, and Sertoli cell only tubules in testis at the dose of $1,355 \mathrm{mg} / \mathrm{kg} /$ day (Fig. 2). If all spermatogonia are destroyed, the "Sertoli only" change occurs and it results in long-term and possibly permanent sterility [18]. In this study, "Sertoli only" change occurred and the atrophy noted in the seminiferous tubules was focally, so that at least some of the germ cell might be survived for the 2-BP treatment period. According to Ichihara et al. $[10,11]$ and Yu et al. [33], atrophy and Sertoli cell only seminiferous tubule were observed in 2-BP-treated male rats. The presence of "Sertoli only" seminiferous tubules on day 21 or 28 after the treatment may be associated with permanent sterility. The non-reversibility of spermatogenic disorders is a point of crucial importance in estimating the testicular effects of 2-BP under an occupational exposure level.

Recent studies have demonstrated that some testicular toxicants cause apoptosis in spermatogenic cells $[2,5,15$, 24, 28, 31]. Apoptosis has recently attracted much attention as a widely documented physiological process by which cells die in a controlled fashion, either spontaneously or in response to changes in the level of specific physiological stimuli $[27,32]$. Germ cell degeneration in the mature mammalian testis occurs both spontaneously during normal spermatogenesis and in response to various environmental agents such as exposure to cytotoxic drugs and chemicals [2]. In situ analysis of TUNEL-positive of the germ cells showed that the germ cell degeneration in adult rats exposed to 2-BP might be due to apoptotic cell death. By the in situ analysis, we demonstrated that the bulk of germ cells undergo apoptosis during 2-BP exposure. On day 14, apoptotic germ cells were significantly higher than the control. In this study, the dramatically increase in germ cell apoptosis was identified as early as 2 weeks, compared to the 3 or 
4 weeks following 2-BP treatment. With increasing exposure time, apoptotic germ cells was decreased. Blanchard et al. [5] reported that apoptosis is a relatively rapid mechanism of cell death. Therefore, it is possible that this apoptotic germ cell mechanism produces the increased germ cell death by the early day and low dose of toxicant exposure.

Most of the spermatogenic cell death induced by 2-BP treatment had characteristics of apoptosis. Electron microscopically, some spermatocytes showed early morphological characteristics of apoptosis. 2-BP produced pathognomonic alterations in the germ cell structure of male rats. A pathway to apoptosis might be associated with the 2BP-induced spermatogenic cell death.

In conclusion, 2-BP caused a testicular atrophy in male rats. The testicular atrophy may be due to cell death, exfoliation of spermatogenic cells in rats. In addition, apoptosis may be involved in spermatogenic cell death and is considered to be a significant determinant in loss of spermatogenic cells in the testis of adult rats after exposure to 2-BP.

ACKNOWLEDGEMENT. This work was supported by the Brain Korea 21 Project.

\section{REFERENCES}

1. Adrien, N., Philippe, L., Francoise, L. M., Christian, D., Catherine, R., Christiane, G., Christian, V. and Elisabeth, B. 1996. In situ apoptotic cell labeling by the TUNEL method: Improvement and evaluation on cell preparations. J. Histochem. Cytochem. 44: 959-968.

2. Allan, D. J., Harmon, B.V. and Kerr, J. F. R. 1987. Cell death in spermatogenesis. pp. 229-257. In: Perspectives on Mammalian Cell Death (Potten, C. S. ed.), Oxford Univ. Press, New York.

3. Allard, E. and Boekelheide, K. 1996. Fate of germ cells in 2,5hexanedione-induced testicular injury. II. Atrophy persists due to a reduced stem cell mass and ongoing apoptosis. Toxicol. Appl. Pharmacol. 137: 149-156.

4. Audring, H., Klug, H., Bollmann, R., Sokolowska-Köhler, W. and Engel, S. 1989. Ureaplasma urealyticum and male infertility: an animal model* II. Morphologic changes of testicular tissue at light microscopic level and electron microscopic findings. Andrologia 21: 66-75.

5. Blanchard, K. T., Allard, E. K. and Boekelheide, K. 1996. Fate of germ cells in 2,5-hexanedione-induced testicular injury. I. Apoptosis is the mechanism of germ cell death. Toxicol. Appl. Pharmacol. 137: 141-148.

6. Blazak, W. F., Treinen, K. A. and Junievicz, P. E. 1993. Application of testicular sperm head counts in the assessment of male reproductive toxicity. pp. 86-94. In: Methods in Toxicology, vol. 3A (Chapin, R. E. and Heindel, J. J. eds.), Academic Press, San Diego.

7. Clermont, Y. and Harvey, S. C. 1965. Duration of the cycle of the seminiferous epithelium of normal, hypophysectomized and hypophysectomized-hormone treated albino rats. Endocrinology 76: 80-89.

8. Creasy, D. M. 1997. Evaluation of testicular toxicity in safety evaluation studies: The appropriate use of spermatogenic staging. Toxicol. Pathol. 25: 119-131.

9. Hess, R. A. and Moore, B. J. 1993. Histological methods for evaluation of the testis. pp. 52-85. In: Methods in Toxicology, vol. 3A (Chapin, R. E. and Heindel, J. J. eds.), Academic Press, San Diego.

10. Ichihara, G., Asaeda, N., Kumazawa, T., Tagawa, Y., Kamijima, M., Yu, X., Konda, H., Nakajima, T., Kitoh, J., Yu, I. J., Moon, Y. H., Hisanaga, N. and Takeuchi, Y. 1996. Testicular toxicity of 2-bromopropane. J. Occup. Health 38: 205-206.

11. Ichihara, G., Asaeda, N., Kumazawa, T., Tagawa, T., Kamijima, M., Yu, X., Kondo, H., Nakajima, T., Kitoh, J., Yu, I. J., Moon, Y. H., Hisanaga, N. and Takeuchi, Y. 1997. Testicular and hematopoietic toxicity of 2-bromopropane, a substitute for ozone layer-depleting chlorofluorocarbons. J. Occup. Health 39: 57-63.

12. Kim, Y. H., Jung, K., Hwang, T., Jung, G., Kim, H., Park, J., Kim, J., Park, J., Park, D., Park, S., Choi, K. and Moon, Y. 1996a. Hematopoietic and reproductive hazards of Korean electronic workers exposed to solvents containing 2-bromopropane. Scand. J. Work Environ. Health 22: 387-391.

13. Kim, Y. H., Chung, Y. H., Yi, K. H., Kim, J. G. and Yu, I. J. 1996b. LC Lo $_{50}$ of 2-bromopropane. Ind. Health 34: 403-407.

14. Korea Industrial Safety Corporation (KISCO), Industrial Health Research Institute. 1995. Final Report of Epidemiological Survey on Yangsan LG Electronics.

15. Ku, W. W., Wine, R. N., Chae, B. Y., Ghanayem, B. I. and Chapin, R. E. 1995. Spermatocyte toxicity of 2-methoxyethanol (ME) in rats and guinea pigs: Evidence for the induction of apoptosis. Toxicol. Appl. Phamacol. 134: 100-110.

16. Lu, C. C. and Meistrich, M. L. 1979. Cytotoxic effects of chemotherapeutic drugs on mouse testis cells. Cancer Res. 39: 3575-3582.

17. Matsui, H., Toyoda, K. and Kawanishi, T. 1996. Advantages of simplified quantitative morphometry using stage grouping analysis of spermatogenic cycle for evaluation of the testicular toxicity of ethylene-1,2-dimethanesulfonate in rats. J. Toxicol. Pathol. 9: 285-292.

18. Meistrich, M. L. 1986. Relationship between spermatogonial stem cell survival and testis function after cytotoxic therapy. Br. J. Cancer 53 (Suppl. VII) 89-101.

19. Nishikawa, Y. 1972. Microscopic observation of sperm. pp. 203-208. In: Mammalian Sperm (Iida, I. et al. eds.). Gakusosya, Tokyo .

20. Nolte, T., Harleman, J. H. and Jahn, W. 1995. Histopathology of chemically induced testicular atrophy in rat. Exp. Toxicol. Pathol. 47: 267-286.

21. Omura, M., Romero, Y., Zhao, M. and Inoue, N. 1999. Histopathological evidence that spermatogonia are the target cells of 2-bromopropane. Toxicol. Lett. 104: 19-26.

22. Omura, M., Zhao, M., Romero, Y. and Inoue, N. 1997. Toxicity of 2-bromopropane on spermatogonia and spermatocyte. $J$. Occup. Health 39: 1-2.

23. Park, J. S., Kim, Y. H., Park, D. W., Choi, K. S., Park, S. H. and Moon, Y. H. 1997. An outbreak of hematopoietic and reproductive disorders due to solvents containing 2-bromopropane in an electronic factory, South Korea: Epidemiological survey. J. Occup. Health 39: 138-143.

24. Richburg, J. H. and Boekelheide, K. 1996. Mono-(2-ethylhexyl) phthalate rapidly alters both sertoli cell vimentin filaments and germ cell apoptosis in young rat testes. Toxicol. Appl. Pharmacol. 137: 42-50.

25. Russell, L. D., Ethllin, R. A., Sinha Hikim, A. P. and Clegg, E. D. 1990. Histopathology of testis. pp. 210-231. In: Histological and Histopathological Evaluation of the Testis (Russell, L. D., Ethllin, R. A., Sinha Hikim, A. P. and Clegg, E. D. eds.). 
Cache River Press, Clearwater, Florida.

26. Saitoh, Y., Usumi, K., Nagata, T., Marumo, H., Imai, K. and Katoh, M. 1997. Early changes in the rat testis induced by di(2-ethylhexyl) phathalate and 2,5-hexanedione: Ultrastructure and lanthanum trace study. J. Toxicol. Pathol. 10: 51-57.

27. Schwartzman, R. A. and Cidlowski, J. A. 1993. Apoptosis: the biochemistry and molecular biology of programmed cell death. Endocrinol. Rev. 14: 133-151.

28. Shinoda, K., Mitsumori, K., Yasuhara, K., Uneyama, C., Onodera, H., Takegawa, K., Takahashi, M. and Umemura, T. 1998. Involvement of apoptosis in the rat germ cell degeneration induced by nitrobenzene. Arch. Toxicol. 72: 296-302.

29. Szczech, G. M. and Russell, L. D. 1997. Commentary on application of refined morphologic evaluation of the testis to the practice of toxicologic pathology. Toxicol. Pathol. 25: 230237.

30. Takahashi, M. and Matsui, H. 1993. Mechanisms of testicular toxicity. J. Toxicol. Pathol. 6: 161-174.
31. Tsuchiya, T., Sano, F., Oikawa, N., Goto, K., Sugimoto, J. and Mutai, M. 1996. Development of ethinylestradiol (EE)-induced testicular atrophy in rats: Involvement of apoptosis in EEinduced spermatogenic cell death. J. Toxicol. Pathol. 9: 359368 .

32. Waring, P., Kos, F. J. and Mullbacher, A. 1991. Apoptosis or programmed cell death. Med. Res. Rev. 11: 219-236.

33. Yu, I. J., Chung, Y. H., Lim, C. H., Maeng, S. H., Lee, J. Y., Lee, S. J., Kim, C. H., Kim, T. G., Lim, C. H., Park, J. S. and Moon, Y. H. 1997. Reproductive toxicity of 2-bromopropane in Sprague Dawley rats. Scand. J. Work Environ. Health 23: 281-288.

34. Yu, X., Kamijima, M., Ichihara, G., Li, W., Kitoh, J., Xie, Z., Shibata, E., Hisanaga, N. and Takeuchi, Y. 1999. 2-Bromopropane causes ovarian dysfunction by damaging primordial follicles and their oocytes in female rats. Toxicol. Appl.Pharmacol. 159: 185-193. 